\title{
Helicobacter pylori ERADICATION USING TETRACYCLINE AND FURAZOLIDONE VERSUS AMOXICILLIN AND AZITHROMYCIN IN LANSOPRAZOLE BASED TRIPLE THERAPY: an open randomized clinical trial
}

\author{
Laura Cidrão FROTA ${ }^{1}$, Maria do Perpétuo Socorro Saldanha da CUNHA ${ }^{2}$, \\ Carlos René Lima LUZ ${ }^{1}$, Antonio Haroldo de ARAUJO-FILHO ${ }^{1}$, \\ Luciano A. S. FROTA ${ }^{1}$ and Lucia Libanez Bessa Campelo BRAGA ${ }^{1}$
}

ABSTRACT - Background - Optimal anti-Helicobacter pylori treatment has not yet been established. Aim - To evaluate H. pylori eradication using tetracycline and furazolidone versus amoxicillin and azithromycin in lansoprazole based triple therapy in northeastern of Brazil. Patients and methods - One hundred and four patients with H. pylori infection, as determined by rapid urease testing and histology, were randomly assigned to receive either: lansoprazole (30 mg q.d.), tetracycline (500 $\mathrm{mg}$ q.i.d.), and furazolidone (200 $\mathrm{mg}$ t.i.d.) for 7 days (LTF; $\mathrm{n}=52)$; or lansoprazole (30 $\mathrm{mg}$ b.i.d.) and amoxicillin (1 $\mathrm{g}$ b.i.d.) for 1 week, plus azithromycin (500 $\mathrm{mg}$ q.d.) for the first 3 days (LAAz; $\mathrm{n}=52$ ). H. pylori eradication was assessed 3 months following completion of therapy by means of rapid urease testing, histology and a ${ }^{14} \mathrm{C}$-urea breath test. Results - H. pylori eradication was achieved in 46 of 52 (88.4\%, 95\% CI: 77.5\%-95.1\%) patients in LTF group and in 14 of 52 (26.9\%, 95\% CI: $16.2 \%-40,1 \%)$ patients in LAAz group. On a per-protocol analysis, eradication rates were $91.8 \%(95 \%$ CI: $81.4 \%-97.3 \%$ ) and 28.5\% (95\% CI: 17.2\%-42.3\%), respectively in LTF and LAAz groups. Conclusion - The LAAz regimen yielded unacceptably low eradication rates. On the other hand, the LTF scheme represents a suitable alternative for H. pylori eradication.

HEADINGS - Helicobacter pylori. Helicobacter infections, chemotherapy. Tetracycline. Furazolidone. Amoxicillin. Azithromycin. Proton pumps, antagonists \& inhibitors.

\section{INTRODUCTION}

Over the past decade, anti-H. pylori therapy has undergone a remarkable evolution. However, optimal treatment has not yet been established, especially in developing countries where such positive results as those reported overseas have not been reproduced.

The standard therapeutic regimen currently available consists of an association of a proton-pump inhibitor
(PPI) and clarithromycin with either amoxicillin or nitroimidazoles ${ }^{(26,28)}$. However, bacterial resistance to nitroimidazoles and increasing resistance to clarithromycin has prompted the search for alternative therapies. Besides that, the optimal regimen strongly depends on many local variables. A regimen useful in one geographical area may not be effective or practical in another area. The issue of cost further complicates the choice, especially in developing and underdeveloped countries. 
Furazolidone is a poorly absorbed antimicrobial agent that is both available and inexpensive in developing countries. In recent years, a number of clinical trials performed with furazolidone have proven its suitable anti-H. pylori activity. To date, resistance to tetracycline and furazolidone seems to be rare (13,23,24) $^{(12}$

Azithromycin is a potentially attractive agent for $H$. pylori eradication given its excellent inhibitory concentration for this organism and long biologic half-life ${ }^{(4,16)}$. However, clinical trials with azithromycin have displayed considerable variation with respect to the regimens used and the results obtained. Eradication rates varying between $93 \%$ and $22 \%$ have been reported ${ }^{(1,3,8,20,29,31)}$. In Brazil, few clinical trials have evaluated the role of azithromycin and furazolidone in the treatment of $H$. pylori infection and most of them have been performed in southeastern of the country ${ }^{(8,28)}$. Since Brazil is a country with continental dimension regional differences are likely to occur.
The aim of this randomized open trial is to evaluate $H$. pylori eradication using tetracycline and furazolidone versus amoxicillin and azithromycin in lansoprazole based triple therapy in northeastern of Brazil.

\section{MATERIALS AND METHODS}

\section{Patient selection}

Dyspeptic patients attending the Division of Gastroenterology of the "Walter Cantídeo" University Hospital (HUWC, Federal University of Ceará, Brazil) with endoscopic diagnoses of peptic ulcer or non-ulcer dyspepsia were invited to participate in the study. Inclusion criteria consisted of $H$. pylori infection, as determined by rapid urease test (RUT) and confirmed by histological examination, age between 18 and 75 years, inclusive, and written informed consent. Exclusion criteria were as follows: previous anti-H. pylori therapy, pregnancy

TABLE 1 - Demographic and clinical characteristics of study patients

\begin{tabular}{|c|c|c|c|}
\hline & $\mathrm{LAAz}$ & LTF & Significance $(P)$ \\
\hline Number of patients & 52 & 52 & \\
\hline Male/female ratio & $27 / 25$ & $25 / 27$ & NS \\
\hline Mean age (SD), years & $40(11)$ & $42(12)$ & NS \\
\hline \multicolumn{4}{|l|}{ Smoking habits $[\mathrm{n}(\%)]$} \\
\hline Non-smokers & $35(53.0 \%)$ & $31(46.9 \%)$ & NS \\
\hline$<=10$ cigarettes $/$ day & $04(33.3 \%)$ & $08(66.6 \%)$ & NS \\
\hline$>10$ cigarettes/day & $13(50.0 \%)$ & $13(50.0 \%)$ & NS \\
\hline \multicolumn{4}{|l|}{ Endoscopic diagnosis [n (\%)] } \\
\hline Duodenal ulcer & $37(49.3 \%)$ & $38(50.67 \%)$ & NS \\
\hline Gastric ulcer & $4(80.0 \%)$ & $1(20.0 \%)$ & NS \\
\hline Gastric and duodenal ulcers & $4(57.1 \%)$ & $3(42.86 \%)$ & NS \\
\hline Gastritis/duodenitis & $7(41.1 \%)$ & $10(58.82 \%)$ & NS \\
\hline
\end{tabular}

LAAz: lansoprazole, amoxicillin and azithromycin

LTF: lansoprazole, tetracycline and furazolidone

TABLE 2 - Compliance and side effects observed in the study groups

\begin{tabular}{|c|c|c|c|}
\hline & $\operatorname{LAAz}(\mathrm{n}=52)$ & $\operatorname{LTF}(\mathrm{n}=52)$ & Significance $(P)$ \\
\hline \multicolumn{4}{|c|}{ Compliance of medication $[\mathrm{n}(\%)]$} \\
\hline Full & $49(94.2 \%)$ & $40(76.9 \%)$ & NS \\
\hline $80-99 \%$ & $2(3.8 \%)$ & $10(19.2 \%)$ & NS \\
\hline$<70 \%$ & 0 & $1(1.9 \%) * * *$ & NS \\
\hline \multicolumn{4}{|c|}{ Severity of side-effects $[\mathrm{n}(\%)]$} \\
\hline None & $29(55.7 \%)$ & $21(40.3 \%)$ & NS \\
\hline Moderate & $2(3.8 \%)$ & $3(5.7 \%)$ & NS \\
\hline Severe & 0 & $1(1.9 \%)$ & NS \\
\hline \multicolumn{4}{|c|}{ Symptoms of side-effects [n( $\%)]$} \\
\hline Diarrhea & $17(32,6 \%)$ & $2(3,8 \%)$ & $P<0,0001$ \\
\hline Nausea & $5(9,6 \%)$ & $18(34,6 \%)$ & $P=0,004$ \\
\hline Pruritus & $2(3,8 \%)$ & $2(3,8 \%)$ & NS \\
\hline Epigastric pain & $1(1,9 \%)$ & - & NS \\
\hline
\end{tabular}

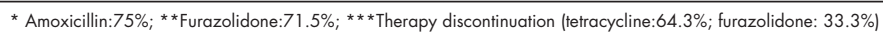


Frota LC, Cunha MPSS, Luz CRL, Araujo-Filho AH, Frota LAS, Braga LLBC. Helicobacter pylori eradication using tetracycline and furazolidone versus amoxicillin and azithromycin in lansoprazole based triple therapy: an open randomized clinical trial

or lactation, gastric surgery (except highly selective vagotomy or oversewing of ulcer perforation), malignancy, severe liver or kidney disease, known or suspected hypersensitivity to the medication used in the study, chronic alcoholism, and suspected lack of compliance, and patients who had previously undergone eradication therapy. These criteria were ascertained by taking a complete history, physical examination, and appropriate hematologic and biochemical tests. The study was approved by the local Ethics Committee.

One hundred and four subjects were selected. Patients' clinical and demographic characteristics are listed in Table 1. None of the differences are significant.

Upper gastrointestinal endoscopy was performed (Pentax EG 2901 videoscope, Japan), and eight gastric biopsies were taken to assess $H$. pylori status (four from the antrum and four from the corpus). Endoscopic and biopsy forceps were thoroughly cleaned with an enzymatic detergent and disinfected with $2 \%$ glutaraldehyde between all procedures. Four specimens (two from both antrum and corpus) were used for RUT, which was performed with a commercially available kit (Laboclin, Minas Gerais, Brazil).

Histologic assessment of $H$. pylori status was performed using further four biopsy specimens (hematoxylin-eosin and Giemsa stain), two from the antrum, and two from the gastric body. $H$. pylori infection was defined when positive results in both the rapid urease test and histology were obtained.

\section{Study design}

Patients were randomized to receive either: 1) lansoprazole (capsules, Medley, São Paulo, Brazil), 30 mg b.i.d. (before breakfast and dinner), plus amoxicillin (capsules, Aché, São Paulo), $1 \mathrm{~g}$ b.i.d. (with breakfast and dinner) for 1 week, and azithromycin (tablets, Libbs, São Paulo), $500 \mathrm{mg}$ once a day (2 hours after lunch) for the first 3 days (LAAz regimen); or 2) lansoprazole (capsules, Medley, São Paulo), 30 mg before breakfast, plus oxytetracycline (capsules, Bristol-Myers Squibb, São Paulo), $500 \mathrm{mg}$ q.i.d., plus furazolidone (tablets, UCI-Farma, São Paulo), $200 \mathrm{mg}$ t.i.d. for 1 week (LTF regimen). Patients with active ulcers were also treated with ranitidine, $300 \mathrm{mg}$ at bedtime for a total of 1 month.

Subjects were asked to record any adverse events occurring during the treatment period and to return for clinical check-up at the completion of the study therapy. Compliance and side-effects were assessed by means of a returned-tablets count and by direct interviews based on the "standard side-effect scoring system in studies exploring $H$. pylori treatment regimens", as proposed by de BOER et al. ${ }^{(10)}$. At this point, patients were also instructed to report to their study physician if they happened to use any other medication considered active against $H$. pylori, such as PPI, bismuth salts, or other antimicrobial agents, until follow-up examination.

Three months after the conclusion of the study therapy, subjects returned for reevaluation $H$. pylori eradication was assessed by endoscopy as at entry. Additionally, all patients underwent a ${ }^{14} \mathrm{C}$-urea breath test $\left({ }^{14} \mathrm{C}\right.$-UBT $)$. The breath test was performed following the instructions of product manufacturer. The ${ }^{14} \mathrm{C}-\mathrm{UBT}$ was performed after a fasting period of 6 hours. The patient swolled a 1 micro Currie capsula of ${ }^{14} \mathrm{C}$-UBT with $200 \mathrm{~mL}$ of water. After 10 minutes, a breath sample was collected. The samples were analysed with a liquid scintillation counter (Tri-Med Specialties Inc. USA). The results were considered positive when DPM $>100^{(26)}$.
Eradication was defined as negative result from all three tests $\left({ }^{14} \mathrm{C}-\mathrm{UBT}\right.$, RUT and histology).

\section{Statistical analysis}

Demographic characteristics, $H$. pylori cure rates and side effects were compared using two-tailed Pearson $\chi^{2}$ and Fischer's exact tests. All patients were evaluated in an intention-to-treat (ITT) analysis, in which patients without final $H$. pylori determination or with protocol violations were considered treatment failures. The per-protocol (PP) analysis included all subjects who took at least $80 \%$ of each study medication as prescribed and who completed the final $H$. pylori status assessment. Statistical significance was set at $P<0.05$.

\section{RESULTS}

One hundred and four patients entered the study. At entry, there were no significant differences between the two groups with regard to age, gender, smoking habits and endoscopic diagnoses (Table 1). Patient compliance, measured by returned-pill count, was considered good for both treatment regimens, with all but three patients taking more than $80 \%$ of their prescribed drugs (Table 2 ).

Both therapies were well tolerated by the most of the patients (Table 2). Although 23 (44.2\%) in the LAAz group and 31 (59.6\%) in the LTF group had experienced any degree of side effect, only 2 $(3.8 \%)$ and $4(7.6 \%)$, respectively in groups LAAz (diarrhea) and LTF (nausea), reported interference with their normal activities. Nevertheless, none of the side effects were considered clinically serious, and all but one patient completed the course.

All 104 patients were included in an ITT analysis. In the PP analysis, three patients were excluded from each group: one subject $(1.9 \%)$ from the LTF group had withdrawn from the study due to treatment side effects (nausea); one patient from each group had taken less than $80 \%$ of the medication as directed, in spite of having completed the treatment; the other three patients excluded had failed to return for follow-up investigation.

Eradication results are shown in Table 3. The overall eradication rate in the LTF group was significantly better than in the LAAz group in both the ITT and PP analysis $(P<0.0001)$. One patient in the LTF group took furazolidone, $200 \mathrm{mg}$ b.i.d. instead of t.i.d., but $H$. pylori was eradicated nonetheless. Another patient in the LAAz group took amoxicillin, $1 \mathrm{~g}$ in the morning plus

TABLE 3 - Overview of treatment results

\begin{tabular}{lccc}
\hline & LAAz & LTF & Significance (P) \\
\hline & & & \\
Number of patients & 52 & 52 & $\mathrm{P}=1.0000$ \\
Patients lost at follow-up [n (\%)] & $2(3.8 \%)$ & $2(3.8 \%)$ & $\mathrm{NS}$ \\
H. pylori eradication & & & \\
Per-protocol [n (\%)] & $14 / 49(28.5 \%)$ & $45 / 49(91.8 \%)$ & $\mathrm{P}<0.0001$ \\
95\% CI & $(17.2-42.3 \%)$ & $(81.4-99.3 \%)$ & \\
Intention-to-treat [n (\%)] & $14 / 52(26.9 \%)$ & $46 / 52(88.4 \%)$ & $\mathrm{P}<0.0001$ \\
95\% CI & $(16.2-40.1 \%)$ & $(77.5-95.1 \%)$ & \\
Smokers [n (\%)] & $3 / 15(20.0 \%)$ & $19 / 20(95.0 \%)$ & $\mathrm{P}<0.0001$ \\
Non smokers [n (\%)] & $11 / 35(31.0 \%)$ & $27 / 30(90.0 \%)$ & $\mathrm{P}<0.0001$ \\
Frequency of side effects & & & \\
Overall [n (\%)] & $23(44.2 \%)$ & $31(59.6 \%)$ & $\mathrm{NS}$ \\
Major [n (\%)] & $2(3.8 \%)$ & $4(7.6 \%)$ & $\mathrm{NS}$ \\
Therapy discontinuation [n (\%)] & 0 & $1 *(1.9 \%)$ & $\mathrm{NS}$ \\
& & & \\
\hline
\end{tabular}

* Naused

$\mathrm{Cl}$ : Confidence Interval 
Frota LC, Cunha MPSS, Luz CRL, Araujo-Filho AH, Frota LAS, Braga LLBC. Helicobacter pylori eradication using tetracycline and furazolidone versus amoxicillin and azithromycin in lansoprazole based triple therapy: an open randomized clinical trial

$500 \mathrm{mg}$ at night, instead of $1 \mathrm{~g}$ b.i.d.; in this case, eradication was unsuccessful.

There was good agreement between RUT, UBT and histology results. The three tests were positive for 38 patients and negative for 60 patients. Histology alone and UBT alone were positive for one patient each.

\section{DISCUSSION}

Choice of the ideal therapeutic scheme for $H$. pylori should be based on treatment effectiveness, safety, tolerability, interaction potential, and medication costs ${ }^{(12)}$.

Azithromycin is a macrolide with excellent in vitro anti- $H$. pylori activity. It also exhibits a particularly attractive pharmacological profile in that, hypothetically, it could also curtail treatment duration, thus improving compliance and reducing costs ${ }^{(25)}$.

Clinical trials with azithromycin have showed considerable variation with respect to the regimens used and the results obtained $\mathrm{d}^{(1,}$ $3,8,17,18,20,29,31)$. Several trials have tested azithromycin $500 \mathrm{mg} / \mathrm{d}$ for 3 days administered in fasting patients, in combination with a PPI and amoxicillin. The cure rates reached, on an ITT analysis, ranged from $93 \%$ to $22 \%{ }^{(7,20)}$. However, when azithromycin was administrated at mealtimes, which reduced its absorption by up to $50 \%{ }^{(15)}$, the cure rates ranged from $28 \%$ to $85 \%(2,6,7,11,32)$.

In this study, while treatment compliance has been highly satisfactory, the efficacy of the LAAz scheme, administered in fasting patients, has been low, with $28.8 \%$ eradication rate in the ITT analysis. In southeastern of Brazil, COELHO et al. ${ }^{(8)}$ reported similar results. This could be attributed to several factors. Recent data suggest that 10- to 14-day triple therapies could achieve higher eradication rates than 7-day schedules ${ }^{(5)}$. CHEY et al. ${ }^{(7)}$ showed that higher dose (1 $\mathrm{g} / \mathrm{d}$ ) of the drug was significantly better at curing $H$. pylori infection. An other possibility, it is that association of azithromycin with amoxicillin elicits a lower synergistic action than that achievable with nitroimidazoles. Resistance of $H$. pylori to azithromycin is another potential factor influencing treatment outcomes.

In the second study group, a combination of lansoprazole, tetracycline, and furazolidone was tested. In this study, the LTF scheme proved effective, with eradication rates of $91.8 \%$ and $88.4 \%$, respectively in the PP and ITT analyses. These results are in agreement with the majority of studies published within the last 5 years that focused on furazolidone in triple or quadruple therapies, considering the heterogeneity of the specific regimens employed ${ }^{(9,19,22)}$.

A major problem with furazolidone is the high rate of severe adverse effects ${ }^{(14,28)}$. Some studies try to identify simpler dosage schemes, thus granting higher treatment conformity and perhaps greater tolerability. MALEKZADEH et al. ${ }^{(21)}$ evaluated omeprazole $20 \mathrm{mg}$, tetracycline $500 \mathrm{mg}$, and furazolidone $200 \mathrm{mg}$ twice daily for 4 days and for 7 days, they found that the eradication rates were unacceptable for $H$. pylori infection. However, MANSOURGHANAEI et al. ${ }^{(22)}$ showed that when the medication were taken for 2 weeks the eradication rate were highly satisfactory.

In this study, we used furazolidone $200 \mathrm{mg} 3$ times for 7 days. It seems that furazolidone $600 \mathrm{mg}$ /day for short period of time ( 7 days) is as effective as 10-14 days at curing $H$. pylori infection and it should have better compliance than 14 days schemes. In our study, $96 \%$ of patients took more than $80 \%$ of the prescribed medication, and only one patient interrupted the treatment plan. This may be explained by the fact that more time is spent with patients entering research protocols. The patients were better informed of the importance of $H$. pylori eradication and many of them chose to tolerate the adverse effects and to finish treatment. Therefore, the inconveniences of this association do not compromise its validity. Future studies may identify simpler dosage schemes, thus yelding greater tolerability.

\section{CONCLUSION}

The results clearly demonstrated that the LAAz regimen for $H$. pylori eradication was ineffectual for the studied population. However, the LTF scheme, although less practical, is effective and may represent an economically viable alternative for $H$. pylori eradication in developing countries.

\section{ACKNOWLEDGEMENT}

Financial support for this study was provided by Brazilian Council of Scientific and Technical Development (CNPq).

We would like to thank to Ms. Rosa Maria Salani for helping in data analysis, Medley Pharmaceutical that kindly provided lansoprazole, and Dr. Dulciene Queiroz that kindly review this manuscripts.

Frota LC, Cunha MPSS, Luz CRL, Araujo-Filho AH, Frota LAS, Braga LLBC. Erradicação de Helicobacter pylori com o uso de tetraciclina e furazolidona versus amoxicilina e azitromicina em terapia tríplice com lansoprazol. Arq Gastroenterol 2005;42(2):111-5.

RESUMO - Racional - Ainda não está estabelecida a melhor terapêutica anti-H. pylori. Objetivo - Avaliar a erradicação de H.pylori usando tetraciclina e furazolidona versus amoxicilina e azitromicina em terapia tríplice com lansoprazol no nordeste do Brasil. Pacientes e métodos Cento e quatro pacientes infectados por H. pylori, diagnosticado através do teste rápido da urease e histologia, foram selecionados aleatoriamente para receber: lansoprazol (30 mg q.d.), tetraciclina (500 mg q.i.d.), furazolidona (200 mg t.i.d.) por 7 dias (LTF; $\mathrm{n}=52)$; ou lansoprazol (30 mg b.i.d.) e amoxicilina ( $1 \mathrm{~g}$ b.i.d.) por 1 semana, mais azitromicina (500 $\mathrm{mg}$ q.d.) nos primeiros 3 dias (LAAz; $\mathrm{n}=52$ ). A erradicação de H.pylori foi avaliada 3 meses após término da terapia através do teste da urease, histologia e teste respiratório usando uréia marcada com ${ }^{14}$ Carbono. Resultado - A erradicação do H. pylori foi atingida em 46 de 52 (88.4\%, 95\% CI: 77.5\%-95.1\%) pacientes no grupo LTF e em 14 de 52 (26.9\%, 95\% CI: 16.2\%-40,1\%) pacientes no grupo LAAz. Na análise per-protocolo, a taxa de erradicação foi de 91.8\% (95\% CI: 81.4\%-97.3\%) e 28.5\% (95\% CI: 17.2\%-42.3\%), respectivamente no grupo de LTF e LAAz. Conclusão - O esquema com LAAz ofereceu taxas de erradicação inaceitáveis. Por outro lado, o esquema com LTF representa alternativa adequada para erradicação de H.pylori.

DESCRITORES - Helicobacter pylori. Infecções por Helicobacter, quimioterapia. Tetraciclina. Furazolidona. Amoxicilina. Azitromicina. Bombas de próton, antagonistas \& inibidores. 


\section{REFERENCES}

1. al-Assi MT, Genta RM, Karttunen TJ, Cole KA, Graham DY. Azithromycin triple therapy for Helicobacter pylori infection: azithromycin, tetracycline, and bismuth. Am J Gastroenterol 1995;90:403-5.

2. Anagnostopoulos GK, Kostopoulos P, Margantinis G, Tsiakos S, Arvanitidis D. Omeprazole plus azithromycin and either amoxicillin or tinidazole for eradication of Helicobacter pylori infection. J Clin Gastroenterol 2003;36:325-8.

3. Bertoni G, Sassatelli R, Nigrisoli E, Tansini P, Bianche G, Della Casa G, Bagni A, Bedogni G. Triple therapy with azithromycin, omeprazole, and amoxicillin is highly effective in the eradication of Helicobacter pylori: a controlled trial versus omeprazole plus amoxicillin. Am J Gastroenterol 1996;9:258-63.

4. Blandizzi C, Malizia T, Gherardi G, Costa F, Marchi S, Marveggio C, Natale G, Senes S, Bellini M, Maltinti G, Campa M, Del Tacca M. Gastric mucosa distribution and clinical efficacy of azithromycin in patients with Helicobacter pylori related gastritis. J Antimicrob Chemother 1998;42:75-82.

5. Calvet X, Garcia N, Lopez T, Gisbert JP, Gene E, Roque K. A meta-analysis of short versus long therapy with a proton pump inhibitor, clarithromycin and either metronidazole or amoxicillin for treating Helicobacter pylori infection. Aliment Pharmacol Ther 2000;14:603-9.

6. Cammarota G, Tursi A, Papa A, Montatto M, Veneto G, Cuoco L, Fedeli G, Gasbamin G. Helicobacter pylori eradication using one-week low-dose lansoprazole plus amoxicillin and either clarithromycin or azithromycin. Aliment Pharmacol Ther 1996;10:997-1000.

7. Chey WD, Fisher L, Barnett J, Delvalle J, Elta GH, Hasler WL, Nostrant T, Palaniappan J, Sheiman J. Low-versus high-dose azithromycin triple therapy for Helicobacter pylori infection. Aliment Pharmacol Ther 1998;12:1263-7.

8. Coelho LGV, Vieira WLS, Passos MCF. Azithromycin, furazolidone and omeprazole: a promising low-dose, low-cost, short-term anti H. pylori triple therapy [abstract]. Gastroenterology 1998;1196:296A.

9. Dani R, Queiroz DM, Dias MG, Franco JM, Magalhães LC, Mendes GS, Moreira LS, De Castro LP, Toppa NH, Rocha GA, Cabral MM, Sales PG. Omeprazole, clarithromycin and furazolidone for the eradication of Helicobacter pylori in patients with duodenal ulcer. Aliment Pharmacol Ther 1999;13:1647-52.

10. de Boer WA, Thys JC, Borody TJ, Graham DY, O’Morain C, Tytgat GN. Proposal for use of a standard side effect scoring system in studies exploring Helicobacter pylori treatment regimens. Eur J Gastroenterol Hepatol 1996;8:641-3.

11. Di Mario F, Dal Bo N, Grassi SA, Rugge M, Cassaro M, Donisi PM, Vianello F, Kusstatscher S, Salandin S, Grasso GA, Ferrana M, Battaglia G. Azithromycin for the cure of Helicobacter pylori infection. Am J Gastroenterol 1996;91:264-7.

12. The European Helicobacter pylori Study Group. Current European concepts in the management of Helicobacter pylori infection. The Maastricht Consensus Report. Gut 1997;41:8-13.

13. Fennerty MB. What are the treatment goals for Helicobacter pylori infection? Gastroenterology 1997;113:120-5.

14. Graham DY. Antibiotic resistance in Helicobacter pylori: implications for therapy. Gastroenterology 1998;115:1272-7.

15. Graham DY, Osato MS, Hoffman J, Opikun AR, Anderson SY, El-Zimaity HM Furazolidone combination therapies for Helicobacter pylori infection in the United States. Aliment Pharmacol Ther 2000;14:211-5.

16. Hopkins S. Clinical toleration and safety of azithromycin. Am J Med 1991;91(Suppl 3A):40-5.
17. Hulten K, Cars O, Hjelm E, Engstrand L. In-vitro active of azitromycin against intracellular Helicobacter pylori. J Antimicrob Chemother 1996;37:483-9

18. Ivashkin VT, Lapina TL, Bondarenko OY, Sklanskaya OA, Grigoriev PY, Vasiliev YV, Yakovenko EP, Gulyaev PV, Fedchenko VI. Azithromycin in a triple therapy for H.pylori eradication in active duodenal ulcer. World J Gastroenterol 2002;8:879-82.

19. Laine L, Estrada R, Trujillo M, Cheybani K, Yeeramian P, Smith S, Neil G. Once-daily therapy for $H$. pylori infection: a randomized comparison of four regimens. Am J Gastroenterol 1999;94:962-6.

20. Liu WZ, Xiao, SD, Shi Y, Wu SM, Zhang DZ, Xu WW, Tytgat GN. Furazolidonecontaining short-term triple therapies are effective in the treatment of Helicobacter pylori infection. Aliment Pharmacol Ther 1999:13:317-22.

21. Lombardo L, Masoero G, Dela Monica D, Pera A. Helicobacter pylori eradication using one-week low-dose lansoprasole plus amoxicillin and azithromycin: failure of a "promising" association [letter]. Ital J Gastroenterol Hepatol 1999;31:266-7

22. Malekzadeh R, Merat S, Derakhshan MH, Siavoshi F, Yazdanbod A, Mikaeli J, Sotoudemanesh R, Sotoudeh M, Farahvash MJ, Nasseri-Moghaddam S, Pourshams A, Dolatshahi S, Abedi B, Babaei M, Arshi S, Majidpour A. Low Helicobacter pylor eradication rates with 4- and 7-day regimens in an Iranian population. J Gastroenterol Hepatol 2003;18:13-7.

23. Mansour-Ghanaei F, Fallah MS, Shafaghi A. Eradication of Helicobacter pylori in duodenal ulcer disease tetracycline \& furazolidone vs. metronidazole \& amoxicillin in omeprazole based triple therapy. Med Sci Monit 2002;8:PI27-30

24. Megraud F. Epidemiology and mechanism of antibiotic resistance in Helicobacter pylori. Gastroenterology 1998;115:1278-82

25. Mendonca S, Ecclissato C, Sartori MS, Godoy AP, Guerzoni RA, Degger M, Pedrazzoli Jr. Prevalence of Helicobacter pylori resistance to metronidazole, clarithromycin, amoxicillin, tetracycline, and furazolidone in Brazil. Helicobacter 2000;5:79-83.

26. Peitz U, Menegatti M, Vaira D, Malfertheiner P. The European meeting on Helicobacter pylori: therapeutic news from Lisbon. Gut 1998;43:66-9.

27. Peura DA, Pambianco DJ, Dye KR, Lind C, Frierson HF, Hoffman SR, Combs MJ, Guilfoyle E, Marshall BJ. Microdose ${ }^{14} \mathrm{C}$-urea breath test offers diagnosis of Helicobacter pylori in 10 minutes. Am J Gastroenterol 1996;91:233-8.

28. Silva FM, Eisig JN, Chehter EZ, Silva JJ, Laudanna AA. Omeprazole, furazolidone, and tetracycline: an eradication treatment for resistant $H$. pylori in Brazilian patients with peptic ulcer disease. Rev Hosp Clin Fac Med São Paulo 2002;57:205-8.

29. Trevisani L, Sartori S, Caselli M, Ruina M, Verdianelli G, Abbasciano V. A four-day low dose triple therapy regimen for the treatment of Helicobacter pylori infection. Am J Gastroenterol 1998;93:390-3.

30. Trevisani L, Sartori S, Galvani F, Ruina M, Caseli M, Verdianelli G, Abbasciano V. Evaluation of a new ultrashort triple therapy for Helicobacter pylori disease. Aliment Pharmacol Ther 1998;12:1269-72.

31. Vcev A, Vceva A, Stimac D, Takac B, Dmitrovic B, Stimac D, Stimac T, Kovac D, Pezerovic D, Blazanovic A, Ivandic A, Karner J. Omeprazole, azithromycin and either amoxicillin or metronidazole in eradication of Helicobacter pylori in duodenal ulcer patients. Aliment Pharmacol Ther 1998;12:453-6.

32. Vcev A, Stimac D, Ivandic A, Vceva A, Takac B, Pezerovic D. Pantoprazole, amoxicillin and either azithromycin or clarithromycin for eradication of Helicobacter pylori in duodenal ulcer. Aliment Pharmacol Ther 2000;14:69-72.

Recebido em 29/6/2004

Aprovado em 9/9/2004 